University of Puget Sound

Sound Ideas

All Faculty Scholarship

Faculty Scholarship

Winter 2018

\title{
Introduction to Special Section on Cannabis
}

Denise M. Glover

University of Puget Sound, dglover@pugetsound.edu

Follow this and additional works at: https://soundideas.pugetsound.edu/faculty_pubs

Part of the Alternative and Complementary Medicine Commons, Medicine and Health Commons, and the Social and Cultural Anthropology Commons

\section{Citation}

Glover, Denise M. 2018. "Introduction to Special Section on Cannabis." Journal of Ethnobiology 38(4):469-472.

This Article is brought to you for free and open access by the Faculty Scholarship at Sound Ideas. It has been accepted for inclusion in All Faculty Scholarship by an authorized administrator of Sound Ideas. For more information, please contact soundideas@pugetsound.edu. 


\section{Introduction to Special Section on Cannabis}

Author(s): Denise M. Glover

Source: Journal of Ethnobiology, 38(4):469-472.

Published By: Society of Ethnobiology

https://doi.org/10.2993/0278-0771-38.4.469

URL: http://www.bioone.org/doi/full/10.2993/0278-0771-38.4.469

BioOne (www.bioone.org) is a nonprofit, online aggregation of core research in the biological, ecological, and environmental sciences. BioOne provides a sustainable online platform for over 170 journals and books published by nonprofit societies, associations, museums, institutions, and presses.

Your use of this PDF, the BioOne Web site, and all posted and associated content indicates your acceptance of BioOne's Terms of Use, available at www.bioone.org/page/ terms of use.

Usage of BioOne content is strictly limited to personal, educational, and non-commercial use. Commercial inquiries or rights and permissions requests should be directed to the individual publisher as copyright holder. 


\title{
Introduction to Special Section on Cannabis
}

\author{
Denise M. Glover ${ }^{1}$
}

Cannabis. Pot. Weed. Marijuana. Ganja. Dope. These are just a handful of terms that are used in North America and beyond for the genus Cannabis. It is a plant with many names and a plant with many lives and accompanying narratives. As cannabis becomes legalized in Canada, the United States, Europe, South America, and elsewhere, interest in knowing more about its social and biological life (or lives) has been growing. A goal of this special section is to bring forth diverse and immersive narratives of cannabis so that this important companion species (Haraway 2003) can be known more fully.

There is some debate as to the classificatory status of cannabis. There is widespread recognition of the genus Cannabis, which is not surprising given what we know about the stability of taxonomic systems at the generic level (Berlin 1992). Linnaeus himself coined Cannabis sativa as the species prevalent in Europe in 1753. In 1785, Lamarck identified a separate species, based on morphological characteristics evidenced in specimens from India, which he named Cannabis indica. Botanists since Linnaeus and Lamarck have both proposed additional species, including Cannabis ruderalis (by Janichevsky in 1924, based on specimens from central Russia), as well as one monotypic species of Cannabis sativa with subspecies and cultivar nomenclature (e.g., Cannabis sativa sativa, Cannabis sativa indica, Cannabis sativa sativa var. spontanea) (Small and Cronquist 1976). More contemporary research in molecu- lar biology has yet to settle the taxonomic disparities.

While these debates about classification are of interest to ethnobiologists and biologists alike for purely "academic" reasons, there are also practical and legal ramifications to the classification of Cannabis. In the 1970s, prominent botanists and ethnobotanists, including Richard Evans Schultes, were consultants on court cases involving cannabis, which was then illegal throughout the United States. A monotypic view was used by prosecutors to argue that possession of cannabis of any kind was criminal. A polytypic view, on the other hand, bolstered arguments from the defense that marijuana referred strictly to Cannabis sativa and not to other species, and thus the possession of other Cannabis species should not be subject to criminal prosecution. Interestingly, Schultes changed his mind at least once on this subject, first embracing a monotypic and then a polytypic approach (Emboden 1981; Small 1975; Small and Cronquist 1976; Watts 2006). In this special section, we circumvent this scientific debate about the taxonomic status of Cannabis and use the common English term cannabis, unless there is desire and/or need to specify genus, species, subspecies, or varietal names.

Cannabis is decidedly indigenous to Eurasia (Clarke and Merlin 2013; Long et al. 2017; McPartland et al. 2018). Early evidence of its connection to human cultures dates back to the early Holocene, with some of the primary evidence (when it 
was likely used as fiber) dating back 7000 yrs BP across much of Eurasia (Clarke and Merlin 2013:75). And yet the life of cannabis was not defined only by this primary site of emergence, as is the case for other keystone species of importance to humannon-human interactions. As people moved from Eurasia, so did cannabis-together as companion travelers. Similar to the migrations of key species in the Solonaceae, Plantacea, and Piperaceae families, Cannabaceae likely traveled with humans due to its extensive utility (as a psychoactive, medicinally, and for material culture), as well as its capacity to encourage reverence; in fact, the two of these qualities are likely linked. The diverse geographic focus of the works included in this special collection (Canada, the United States, the Congo Basin, and northern India) is a testament to the expansive reach of ethnobiological research on this topic, but also to the wide spread of cannabis and the widespread importance of human-cannabis relations.

Globally, within the past century, cannabis has vacillated between the extremes of the illegal and the legal. At one time, not even under any guise of legal classification one way or another, cannabis was essentially "invisible" (Scott 1999) to many nation-states. With the establishment of the 1961 United National Convention on Narcotic Drugs and subsequent national laws outlawing cannabis in the United States, Canada, India, many countries in Europe, East and Southeast Asia, and Latin America, cannabis was thrust into the spotlight of governmental control and domination. In the past decade or two, beginning in Europe and then spreading to North America, shifts in governmental policy have loosened in some nation-states. Canada has legalized cannabis nationwide, following similar legislation in Uruguay, South Africa, and several states in the United States. At the time of writing (late 2018), approximately 30 countries world-wide have decriminalized cannabis, about 34 allow medical uses of cannabis, and 25 permit cultivation of cannabis for some usage (many require permits).

Today, cannabis has taken on new powers and agency - in the marketplace, at the voter's polls, and in international trade. This agency renders cannabis a significant actant (Latour 2005) in a complex web of human and non-human actors. Even where legal or decriminalized, cannabis is highly visible to the state, often with close monitoring of growing and consumption. In the United States, federal and state law are in many places at odds with each other, and the consequences of conflicting legal status have yet to play out in full. In addition, cannabis has, in many ways, become an accomplice to state and intrastate commerce, as income and wealth accumulate through sales and research in cannabis, particularly in its medicinal applications. Erica Lagalisse discusses how uneven distributions and accumulations of cultural, social, and economic capital in North America have been both formed and informed by dichotomous renderings of legal vs. non-legal cannabis; on the one hand, is legal, often medical, cannabis, associated with wealth and privilege (and often state power), while on the other, illegal cannabis is associated with marginalized and minoritized groups. The social and political stigma that was long associated with cannabis use for much of the twentieth century in North America (and now is associated with certain, largely minoritized, groups) and cannabis' transformation out of the "shadows" in the twenty-first century is explored by Sunil Aggarwal in his memoir-style contribution. His narrative is made particularly compelling due to the intersection of Aggarwal's own cultural and professional identities as a South-Asian American medical doctor and geographer.

Recent national and international research on cannabis has yielded an understanding of the cannabinoid structures in 
cannabis, as well as the endocannabinoid system in the human body, suggesting that there are significant biochemical linkages between our species and cannabis (Mackie 2008; Russo 2016). Just what those linkages mean in terms of evolutionary pressure is not totally clear. Endocannabinoid receptors evolved in primitive organisms approximately 600 million years ago and cannabis itself evolved perhaps not more than 34 million years ago (McPartland 2008:588). This suggests that evolutionary forces did not exert pressure for an endocannabinoid system to develop in early primates in response to cannabis, since it was already established as a biochemical system in our ancestors before cannabis itself evolved. Perhaps the vector of change came on the side of cannabis. Perhaps cannabis evolved cannabinoids to "hook up" with humans to propagate itself, as Michael Pollan has argued may be the case for corn (Pollan 2006), or we might infer from Richard Doyle's (2011) discussion of how psychedelic plants seduced humans and became active participants in the creation of many human cultural traditions. We still do not know for sure. Either way, because of the interlocking mechanisms of cannabinoid receptors in human (and other non-human, Cordate) bodies and cannabinoid chemicals in cannabis which bind to these receptors, a fairly extensive chemical and cultural relationship has developed between humans and cannabis in disparate locations in the world. Due to the long-term, interactive relationship between humans and cannabis, we can consider humans and cannabis as companion species. The human-cannabis relationship is especially developed in the area of healing traditions and/or altered states of mind and body. All contributions in this special section touch on these aspects of the companion relationship. Sunil Aggarwal, in particular, discusses the significance of biochemical findings in terms of psychological and physiological healing and a sense of connectedness to a unity of beings, similar to what Richard Doyle has referred to as an experience of holarchy (Doyle 2012, after Margulis and Sagan 2000).

As cannabis receives much media attention and alignment with various causes, especially in countries in the Global North, in the forests of sub-saharan Africa and high in the mountains of the Himalayas, cannabis can be found either seemingly plodding along with minor shifts in usage and meaning or staging its own less publicized revolution. A crop under long-term cultivation for various purposes in these areas of the world, cannabis has taken on a new life and new socio-cultural meanings, particularly in India. Prasenjeet Tribhuvan discusses the agency of cannabis in social transformations in the Indian Himalayas, many of which are not positive, principally under the influence of a widening global trade in cannabis. Tribhuvan argues that cannabis was once a "humble" object of practical everyday usage in the Himalayas but has now become a "transgressive," powerful actant in a complex network of human and non-human actors (per Latour 2005) with the power to bring wealth (with some advantages), as well as destruction to families. In the Congo Basin of central Africa, shifts in consumption, usage, and trade are discussed by Roulette and Hewlett, yet the transformative power of cannabis in this area of the world seems less pronounced. Roulette and Hewlett's contribution gives us some perspective on cannabis usage and meaning in the Congo Basin, as the article is based on longitudinal research spanning 40 years; thus, the authors discuss continuities, as well as slight shifts, especially due to engagement with a market economy.

The understanding we are left with from the four contributions in this special section is that the cannabis-human relationship is an evolving one, subject to socio-cultural, economic, and political shifts at the national, as well as interna- 
tional, levels. Undoubtedly other vectors of change emanate from and interact on a biochemical level as well, although those are not explored in depth in this special issue. As this relationship deepens, so do the complexities of the relationship; further ethnobiological research will be needed in this field for many years to come.

\section{References Cited}

Berlin, B. 1992. Ethnobiological Classification: Principles of Categorization of Plants and Animals in Traditional Societies. Princeton University Press, Princeton, New Jersey.

Clarke, R. C., and M. D. Merlin. 2013. Cannabis: Evolution and Ethnobotany. University of California Press, Berkeley.

Doyle, R. 2011. Darwin's Pharmacy: Sex, Plants, and the Evolution of the Noosphere. University of Washington Press, Seattle.

Doyle, R. 2012. Healing with Plant Intelligence. Anthropology of Consciousness 23:28-43.

Emboden, W. A. 1981. The Genus Cannabis and the Correct Use of Taxonomic Categories. Journal of Psychoactive Drugs 13:15-21.

Haraway, D. 2003. The Companion Species Manifesto: Dogs, People, and Significant Others. Prickly Paradigm, Chicago.

Latour, B. 2005. Reassembling the Social: An Introduction to the Actor Network Theory. Oxford University Press, London.

Long, T., M. Wagner, D. Demske, C. Leipe, and P. E. Tarasov. 2017. Cannabis in Eurasia: Origin of Human Use and Bronze Age Trans-Continental Connections. Vegetation History and Archaeobotany 26:245-258.
Mackie, K. 2008. Cannabinoid Receptors: Where They Are and What They Do. Journal of Neuroendocrinology 20:10-14.

Margulis, L., and D. Sagan. 2000. What Is Life? University of California Press, Berkeley.

McPartland, J. M. 2008. The Endocannabinoid System: An Osteopathic Perspective. Journal of American Osteopathic Association 108:586-600.

McPartland, J. M., G. W. Guy, and W. Hegman. 2018. Cannabis is Indigenous to Europe and Cultivation Began During the Copper or Bronze Age: A Probabilistic Synthesis of Fossil Pollen Studies. Vegetation History and Archaeobotany 27:635-648.

Pollan, M. 2006. The Omnivore's Dilemma: A Natural History of Four Meals. Penguin Books, London.

Russo, E. 2016. Beyond Cannabis: Plants and the Endocannabinoid System. Trends in Pharmacological Sciences 37:594-605.

Scott, J. 1999. Seeing Like a State: How Certain Schemes to Improve the Human Condition Have Failed. Yale University Press, New Haven, Connecticut.

Small. E. 1975. On Toadstool Soup and Legal Species of Marihuana. Plant Science Bulletin 21:35-39.

Small, E., and A. Cronquist. 1976. A Practical and Natural Taxonomy for Cannabis. Taxon 25:405-435.

Watts, G. 2006. Science Commentary: Cannabis Confusions. British Medical Journal 332:175-176. 